Transactions of the American Fisheries Society, Vol. 127, No. 6, 1998, pp.1040-1050

ISSN: (print 0002-8487) (online 1548-8659)

DOI: $10.1577 / 1548-8659(1998) 127<1040:$ PSBLFA $>2.0 . C O ; 2$

http://www.fisheries.org/afs/

http://afsjournals.org/loi/fitr

http://afsjournals.org/doi/pdf/10.1577/1548-8659\%281998\%29127\%3C1040\%3APSBLFA\%3E2.0.CO\%3B2

(C) 1998 American Fisheries Society 


\title{
Prey Selection by Larval Fishes as Influenced by Available Zooplankton and Gape Limitation
}

\author{
DenNis R. DeVRIES* \\ Department of Fisheries and Allied Aquacultures, Alabama Agricultural Experiment Station \\ Auburn University, Alabama 36849-5419, USA
}

Mary T. Bremigan ${ }^{1}$ And Roy A. Stein

Aquatic Ecology Laboratory, Department of Zoology, The Ohio State University 1314 Kinnear Road, Columbus, Ohio 43212-1194, USA

\begin{abstract}
Feeding success during the first weeks of life is critical to determining survival and ultimate year-class strength of fishes. To compare the relative influence of gape limitation and available zooplankton on prey size selection among the larvae of three species of freshwater fishes, we gathered data on fish gape size, prey size, and size-specific prey selection in lakes and reservoirs. These variables were compared among black crappies Pomoxis nigromaculatus from a lake that contained large zooplankton as prey and white crappies $P$. annularis and gizzard shad Dorosoma cepedianum (a potential competitor of white crappie) from reservoirs that contained small zooplankton. In three Ohio reservoirs (i.e., small-zooplankton systems), available zooplankton and larval stages of white crappies and gizzard shad were collected once per week during April through September 1987 and 1988. Although mean prey size of white crappies continued to increase with fish size, mean prey size of smaller-gaped gizzard shad did not. However, as documented for black crappies in north-temperate lakes, white crappies in reservoirs continued to consume prey that were smaller than other available prey, even when they were no longer gape limited. Thus, although the potential for gape limitation differed between large- and small-zooplankton assemblages, prey selection did not differ as expected. Given between-species prey size selection, gizzard shad (that prefer small zooplankton) should be relatively more successful in reservoirs with small zooplankton, whereas white and black crappies (that prefer large zooplankton) should have better success in lakes with large zooplankton.
\end{abstract}

\section{Introduction}

Because survival during the first weeks of life often determines recruitment success of freshwater and marine fishes (Toetz 1966; Rice et al. 1987; Houde 1994), understanding what controls survival during this period will improve our ability to predict year-class strength. For many fishes, foraging success during early larval stages is critical to their survival. As gape-limited predators, larval fish are initially constrained to small zooplankton prey; therefore, during the time when they are gape limited, availability of small, vulnerable zooplankton should influence larval success (Rosenthal and Hempel 1970; Wong and Ward 1972; Zaret 1980; Hansen and Wahl 1981). Prey availability to larvae increases as larvae grow, given that their minimum prey size remains relatively constant (e.g., Schael et al. 1991), whereas their ability to consume larger prey increases progressively. Considering lar-

\footnotetext{
* Corresponding author: ddevries@ acesag.auburn.edu

${ }^{1}$ Present address: Department of Fish and Wildlife, Michigan State University, East Lansing, Michigan 48824, USA.
}

vae beyond the size most constrained by gape limitation, both experiments and field studies have demonstrated that relatively larger zooplankton can promote larval foraging success, growth, and survival (Crowder et al. 1987; Mills et al. 1989a, 1989b; Miller et al. 1990). In contrast, Bremigan and Stein (1997) recently demonstrated that small zooplankton promote survival in larval gizzard shad Dorosoma cepedianum in both the laboratory and field. Indeed, their laboratory experiments (Bremigan and Stein 1994) revealed species-specific relationships among larval gape, zooplankton size, and prey selectivity. Thus, different-sized zooplankton assemblages were postulated to enhance recruitment of different fish species (Bremigan and Stein 1994).

Herein, we provide two field assessments that directly compare relationships among larval gape size, zooplankton size, and larval foraging success. First, we compare diets of two congeners with similar gapes but from systems with different zooplankton assemblages to determine whether differences in available zooplankton size alter patterns of larval prey selection. Specifically, we compare gape size-prey size relationships between 
black crappies Pomoxis nigromaculatus from a large-zooplankton environment, (Lake Mendota, Wisconsin) and white crappies $P$. annularis from small-zooplankton environments (Ohio reservoirs). We expected that mean prey size would be more strongly related to fish size over a broader larval size range in the north-temperate natural lakes than in reservoirs. Second, we compare prey size selection of two species with very different gape sizes experiencing similar zooplankton assemblages to determine whether gape differences between species lead to different durations of gape limitation and mediate competitive interactions. Specifically, we compare gape size-prey size relationships between larval white crappies and gizzard shad because gizzard shad commonly co-occur with white crappies in reservoirs yet have been implicated in crappie decline in experimental ponds (Guest et al. 1990). We expected that mean prey size and fish length (as a surrogate for gape size) would be more strongly related for gizzard shad than for white crappies because of the prolonged gape limitation in gizzard shad. To explicitly evaluate the potential for interspecific competition, we assessed the extent to which these two species overlapped in space, time, and diet.

\section{Methods}

We began with two comparisons. To assess how zooplankton availability might influence gape limitation and prey size selection by larvae with similar gapes, we compared information on zooplankton size, black crappie gape size, and prey size selection in Lake Mendota, Wisconsin (Schael et al. 1991), with similar information on white crappies in Ohio reservoirs. Further, to assess how difference in gape size might influence foraging patterns between species in similar zooplankton environments, we compared white crappies with gizzard shad in Ohio reservoirs.

Whereas the methodological details regarding the Lake Mendota work are available (Schael et al. 1991), we summarize our reservoir methods below.

Study reservoirs.-Larval fish and zooplankton were collected from three Ohio reservoirs. These systems were all shallow, turbid reservoirs with similar areas, maximum depths, and Secchi depths (Clark Lake: area $=40$ ha, maximum depth $=2$ $\mathrm{m}$, Secchi depths $=25-75 \mathrm{~cm}$; Stonelick Lake: 69 ha, $4 \mathrm{~m}, 22-119 \mathrm{~cm}$; Kokosing Lake: 65 ha, $5 \mathrm{~m},<100 \mathrm{~cm})$. For lake descriptions, see DeVries et al. (1991) and DeVries and Stein (1992). Larval gizzard shad were collected from Kokosing Lake.
Because larval white crappies are not abundant in Ohio reservoirs that contained gizzard shad (Miller and Hall 1987; Bremigan et al. 1991), we collected larval white crappies from Clark and Stonelick lakes (lakes without gizzard shad) to quantify their gape size and prey size selection. In Kokosing Lake, larval gizzard shad and white crappies were sampled, and their temporal overlap assessed. Too few white crappies were collected in Kokosing Lake to permit diet analysis.

Sampling methods and laboratory analysis.Larval fishes and zooplankton were collected once per week in each Ohio lake during April through September 1987 and 1988. Integrated water column samples for zooplankton (three replicate samples per date, two columns per sample in Clark and Stonelick lakes, four columns per sample in Kokosing Lake) were collected at the same time as larval fish samples by means of a 2-m tube sampler (7.30-cm inside diameter, 54- $\mu \mathrm{m}$ mesh; DeVries and Stein 1991). Samples were preserved in 5\% sucrose-formalin (Haney and Hall 1973). When fewer than 200 individuals per taxonomic group were captured, all were counted in the sample; $10 \%$ subsamples were counted for abundant taxa until at least 200 individuals of that taxon were counted. At least 20 randomly selected individuals within each taxon were measured (cladocerans were measured from the anterior portion of the carapace to the base of the basal spine; copepods were measured from the anterior portion of the carapace to the base of the caudal rami).

Larval fishes were collected by two replicate daytime surface tows with a 0.75-m-diameter ichthyoplankton net (2 m long, 500- $\mu \mathrm{m}$ mesh, towed at $>1.5 \mathrm{~m} / \mathrm{s}$ ). A flowmeter in the mouth of the net allowed calculation of towing speed and water volume filtered. Samples were preserved in formalin and returned to the laboratory, where they were identified and a subsample measured (up to 50 individuals/sample, nearest millimeter total length, TL). Diets of at least 10 larval white crappies and 10 gizzard shad/sample for each date were quantified with a dissecting microscope. All prey were then identified and measured (nearest $0.1 \mathrm{~mm}$ with a drawing tube and a digitizing tablet, as described for zooplankton analysis above).

Prey selection was quantified with Chesson's alpha (Chesson 1978, 1983), based on prey sizeclasses rather than prey taxa. Size-classes were defined as less than $0.25 \mathrm{~mm}, 0.25-0.50 \mathrm{~mm}$, $0.50-1.00 \mathrm{~mm}$, and greater than $1.00 \mathrm{~mm}$ to be consistent with Schael et al. (1991). Chesson's alpha is defined as 


$$
\alpha=\frac{r_{i} / p_{i}}{\sum_{i}^{m}\left(r_{i} / p_{i}\right)}, i=1, \ldots, m,
$$

where $r_{i}=$ the proportion of prey size-class $i$ in the fish's diet, $p_{i}=$ the proportion of prey sizeclass $i$ in the lake, and $m=$ the number of prey size-classes in the lake (i.e., $m=3$ or 4 ). With this index, a value of $\alpha=(1 / m)$ occurs when the prey size-class is consumed in proportion to its abundance in the environment; values greater than $1 / m$ indicate positive selection, and values less than $1 / m$ indicate negative selection.

Gape size comparisons.-We compared gape size-total length relationships among black crappies, white crappies, and gizzard shad. To determine if gape size varied between black crappies and white crappies, we compared gape measurements of black crappies by Schael et al. (1991), who used a precision gape micrometer (as described by Arts and Evans 1987), with our gape size measurements of white crappies. To measure both white crappie and gizzard shad gapes, we physically opened the mouth of the fish with jeweler's forceps and measured maximum dorsoventral gape with an ocular micrometer (nearest 0.18 $\mathrm{mm}$ ). Gapes were measured on larvae from which diets were also analyzed in 1987 . Doing so allowed us to compare gape sizes of white crappies and gizzard shad and to compare these measurements of gizzard shad gape with those of Bremigan and Stein (1994), who used a gape micrometer similar to Schael et al. (1991).

\section{Results}

\section{Comparison of Zooplankton Assemblages}

To determine if available zooplankton size might influence prey size selectivity of larval fishes with similar gape sizes, we first compared the size distribution of zooplankton in our three Ohio reservoirs (Figure 1) with the zooplankton assemblage in Lake Mendota (Schael et al. 1991). During June-July, an average of approximately 30\% of zooplankton were greater than $1.0 \mathrm{~mm}$ in Lake Mendota, whereas less than $1 \%$ of zooplankton in three Ohio reservoirs were greater than $1.0 \mathrm{~mm}$. In both Lake Mendota and Ohio reservoirs, zooplankton $0.5-1.0 \mathrm{~mm}$ contributed about $30 \%$ of the zooplankton assemblage. Smaller zooplankton $(<0.25 \mathrm{~mm}$ and $0.25-0.50 \mathrm{~mm})$ were more prevalent in Ohio reservoirs (contributing 30\% and $40 \%$, respectively) than in Lake Mendota (21\% and $20 \%$, respectively). Zooplankton density in Ohio reservoirs (mean density in May-June ranged

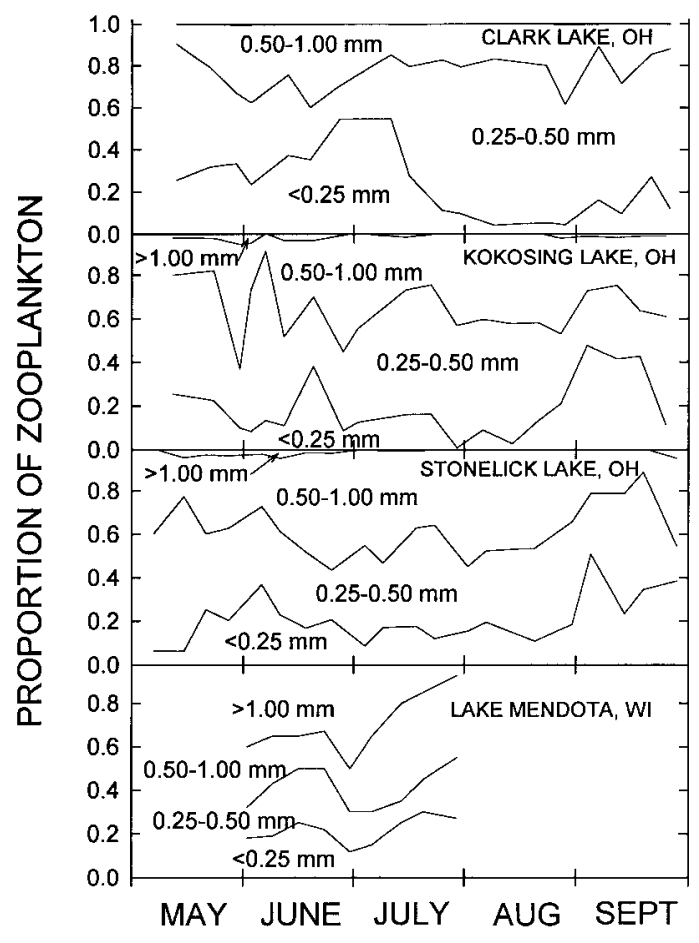

FIGURE 1.-The proportion of zooplankton, by number, in each of four size-classes, from three Ohio $(\mathrm{OH})$ reservoirs during 1987, and from Lake Mendota, Wisconsin (WI; data from Schael et al. 1991). Ohio reservoir data are based on three replicate tube samples per date and at least 10 individual measurements per taxon per sample.

from 410 to 823 organisms/L in Clark and Stonelick lakes) exceeded that in Lake Mendota (mean density $=32$ organisms/L) by an order of magnitude (DeVries et al. 1991; Schael et al. 1991).

\section{Larval Gape Sizes}

White crappie gape increased linearly with fish size in Clark and Stonelick lakes; relationships did not differ between reservoirs (analysis of covariance, ANCOVA, slope: $F=1.73$, df $=1,93, P$ $=0.19$; intercept: $F=0.04$, df $=1,93, P=0.85$; Table 1; Figure 2). Although we used a different measurement method (opening the mouth with a forceps) relative to Schael et al. (1991, use of a gape micrometer) and black instead of white crappies, neither intercept nor slope differed (c.f., Table 1 and Table 1 in Schael et al. 1991) between these two species.

Gape also increased linearly with fish size for Kokosing Lake gizzard shad (Table 1; Figure 2). Though the slope of our relationship did not differ from that generated by Bremigan and Stein (1994), 
TABLE 1.-Linear regression of gape size on fish length for larval white crappies collected from Clark and Stonelick lakes and for gizzard shad in Kokosing Lake, Ohio, 1987-1988. Data are also shown for larval black crappies in Lake Mendota, Wisconsin (from Schael et al. 1991), and for gizzard shad from Hebron Fish Hatchery, Hebron, Ohio (from Bremigan and Stein 1994), and Lake Francis Case, South Dakota (from Michaletz et al. 1987). The equation is of the form: gape $=($ slope $\times$ length $)+$ intercept. Parenthetical values are SEs; NR $=$ not reported.

\begin{tabular}{|c|c|c|c|c|c|}
\hline Species and lake & $\begin{array}{l}\text { Length range } \\
(\mathrm{mm})\end{array}$ & $N$ & Slope (SE) & Intercept (SE) & $r^{2}$ \\
\hline \multicolumn{6}{|l|}{ Crappie ${ }^{a}$} \\
\hline Clark Lake & $4.4-23.4$ & 58 & $0.154(0.004)$ & $-0.419(0.055)$ & 0.94 \\
\hline Stonelick Lake & $4.9-21.4$ & 39 & $0.163(0.005)$ & $-0.404(0.060)$ & 0.96 \\
\hline Clark and Stonelick lakes & $4.4-23.4$ & 97 & $0.158(0.004)$ & $-0.417(0.043)$ & 0.95 \\
\hline Lake Mendota & $5.9-18.4$ & 162 & $0.161(0.007)$ & $-0.656(0.093)$ & 0.75 \\
\hline \multicolumn{6}{|l|}{ Gizzard shad } \\
\hline Kokosing Lake & $9.7-29.2$ & 40 & $0.104(0.007)$ & $-0.712(0.119)$ & 0.82 \\
\hline Hebron Fish Hatchery & $16-30$ & 47 & $0.088 \quad \mathrm{NR}$ & $-0.967 \mathrm{NR}$ & 0.92 \\
\hline Lake Francis Case & a & 26 & $0.070 \quad \mathrm{NR}$ & $-0.178 \quad \mathrm{NR}$ & 0.87 \\
\hline
\end{tabular}

a No individual data points were given; we estimated the length range of the mean values from the provided regression line.

our intercept appeared higher. Further, our relationship (both slope and intercept) appeared to differ from that found by Michaletz et al. (1987); without estimates of variation or size range of fish, their data could not be directly compared with our findings. Why gape measurements differed between techniques for gizzard shad and not for crap- pies is unclear, although this difference may derive from our use of smaller fish relative to those used in these previous studies (from Figures $2-4$ in Michaletz et al. 1987, their sizes of gizzard shad appeared to range from 25 to $55 \mathrm{~mm}$ TL). Gape of Kokosing Lake gizzard shad collected in 1987 was smaller than the gape of Stonelick and Clark

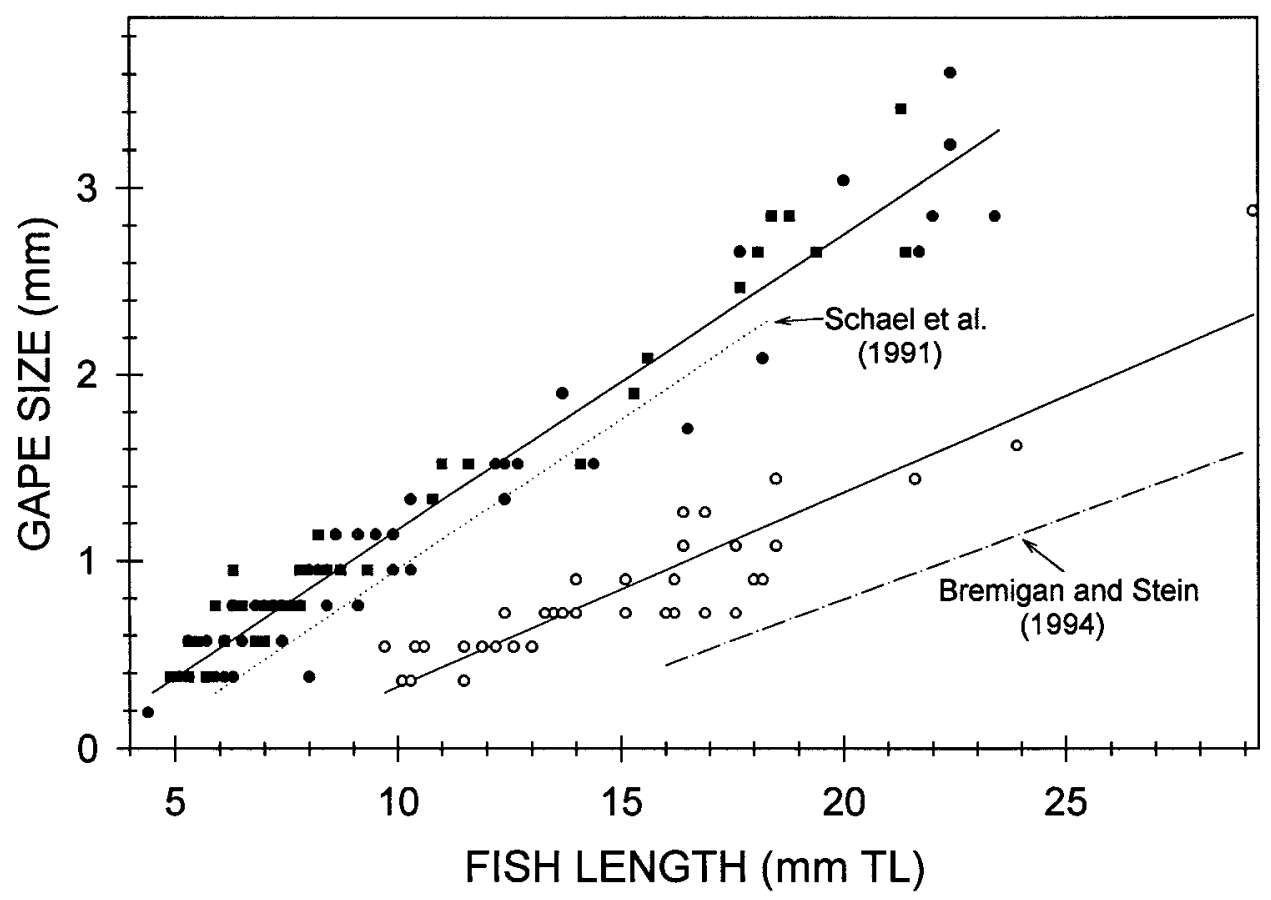

FigURE 2.-Gape size as a function of total length for young-of-year white crappies from Clark (black circles) and Stonelick (black squares) lakes, Ohio, and for gizzard shad (open circles) in Kokosing Lake, Ohio. Regression lines for black crappies from Lake Mendota, Wisconsin (dotted line; Schael et al. 1991) and gizzard shad from Hebron State Fish Hatchery, Ohio (dashed line; Bremigan and Stein 1994), are included for comparison. See Table 1 for regression statistics. 


\section{WHITE CRAPPIE}

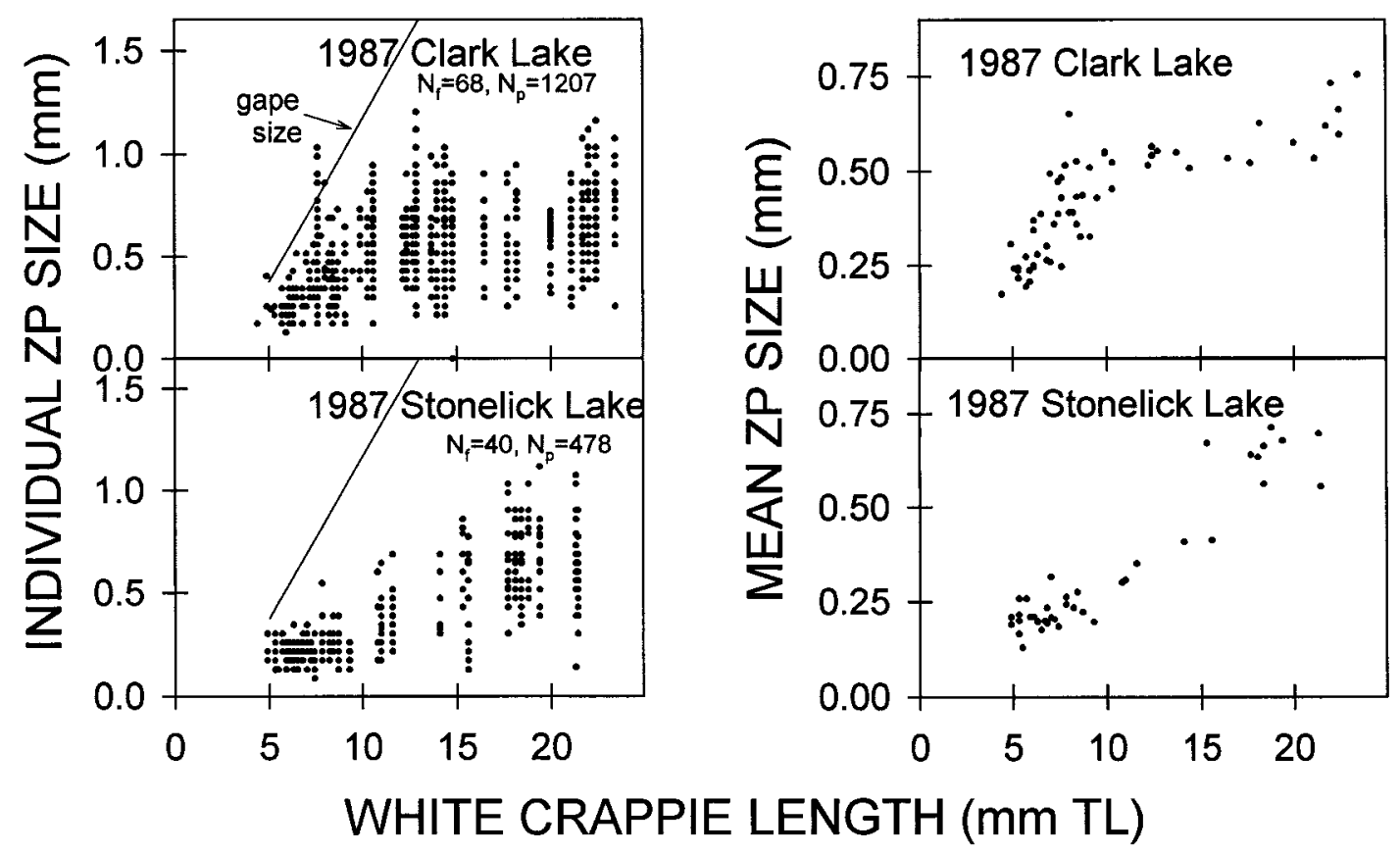

FIGURE 3.- Relationship between individual prey ( $\mathrm{ZP}=$ zooplankton) size and fish total length (left panels) and between mean prey (ZP) size (averaged within individual fish) and fish total length (right panels) for white crappies in Clark and Stonelick lakes, Ohio, during 1987; $N_{f}=$ number of fish whose diets were quantified; $N_{p}=$ number of prey items measured. Lines represent the regression of gape diameter $(\mathrm{mm})$ on fish length ( $\mathrm{mm}$ total length, TL). In the left panels, multiple data points derive from individual fish. Trends in 1988 were similar to those presented here for 1987.

lake white crappies collected in 1987 (ANCOVA, $F=39.57$, df $=1,133, P=0.0001)$. Despite these differences among studies and measurement techniques, all methods found gizzard shad gape size to be small relative to the same size crappies.

\section{Prey Size Selectivity}

As found by Schael et al. (1991) for larval black crappies, the range of prey sizes consumed by larval white crappies increased with fish size (range $=4.4-23.4 \mathrm{~mm}$ ), though gape limitation appeared unimportant beyond about $10 \mathrm{~mm}$ (from comparison of the gape diameter line and individual prey sizes in Figure 3), indicating that gape size increased with fish length more rapidly than did prey size. Mean prey size increased linearly with white crappie size in Stonelick Lake (1987: $F=310.2$, df $=1,38, P=0.0001, r^{2}=0.89 ; 1988: F=$ 28.5, df $=1,41, P=0.0001, r^{2}=0.40$; Figure 3 ) and as the negative exponential of fish size in Clark Lake (1987: $F=156.7$, df $=1,67, P=$ $0.0001, r^{2}=0.70 ; 1988: F=102.1$, df $=1,66$,
$P=0.0001, r^{2}=0.60 ;$ Figure 3$)$. Thus, mean prey size did not increase with fish length for white crappies greater than $10 \mathrm{~mm}$ in Clark Lake (1987: $F=1.64$, df $=1,24, P=0.21, r^{2}=0.03 ; 1988$ : $\left.F=3.07, \mathrm{df}=1,43, P=0.09, r^{2}=0.04\right)$, reaching an asymptote at a prey size of between 0.50 and $0.75 \mathrm{~mm}$. In both reservoirs and Lake Mendota, mean prey size typically increased from 0.25 to $0.75 \mathrm{~mm}$ for larvae $5-23 \mathrm{~mm}$. Mean prey size and fish size were more strongly correlated in Stonelick and Clark lakes than for black crappies in Lake Mendota, Wisconsin (Schael et al. 1991). Thus, despite differences in zooplankton size distributions, patterns in gape limitation appeared similar across systems.

White crappies $10 \mathrm{~mm}$ or less in Stonelick Lake selected positively or neutrally for small $(<0.25$ $\mathrm{mm}$ ) prey, whereas white crappies greater than 10 $\mathrm{mm}$ exhibited negative selection for small prey (Figure 4). Only the smallest white crappies in Clark Lake positively selected small prey, whereas larger fish $(\geq 6 \mathrm{~mm})$ showed neutral to negative 


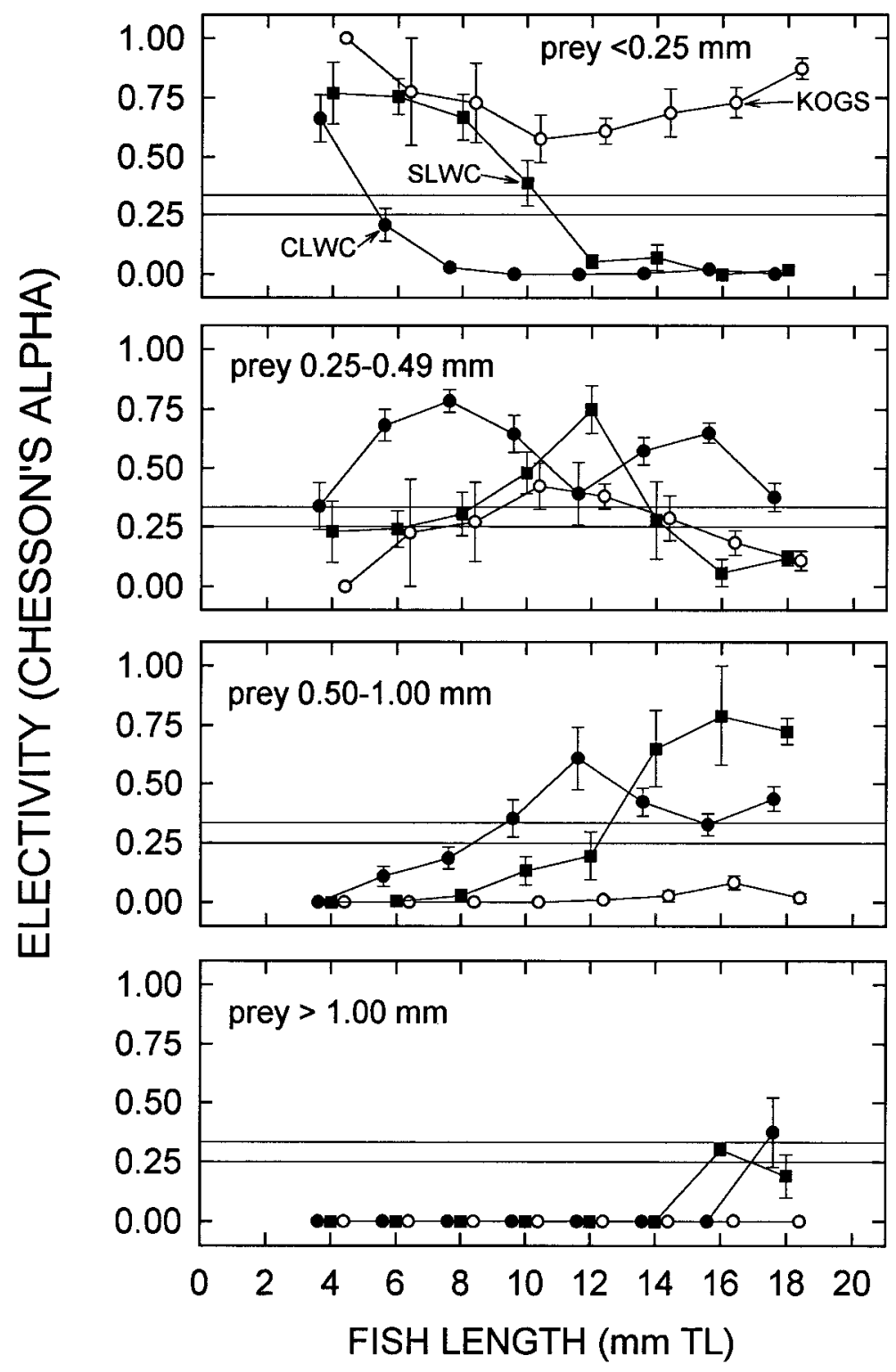

FiguRE 4.-Mean (+SE) prey (zooplankton) selection, measured as Chesson's alpha, as a function of fish length and prey size for white crappies in Clark (CLWC, solid circles) and Stonelick (SLWC, solid squares) lakes and for gizzard shad in Kokosing Lake (KOGS, open circles), Ohio. The region of neutral selection (i.e., $1 / m$, where $m=$ the number of available prey size-classes) is indicated by the area between the solid horizontal lines.

selection (Figure 4). White crappies in both reservoirs showed positive or neutral selection for $0.25-0.49$ and $0.50-1.0-\mathrm{mm}$ prey with increasing fish size. White crappies $14-16 \mathrm{~mm}$ or less in both reservoirs either selected against or expressed neutral selection for the largest prey size-class $(>1.0$ $\mathrm{mm}$; Figure 4). Size selectivity was identical to that quantified for black crappies in Lake Mendota
(Schael et al. 1991), revealing that patterns of prey size selectivity with fish size were consistent, regardless of available zooplankton. Relative to prey taxa, white crappies positively selected copepod nauplii, calanoid copepods, and Diaphanosoma in both reservoirs during both years.

During both 1987 and 1988, larval white crappies and larval gizzard shad occurred and over- 


\section{KOKOSING LAKE GIZZARD SHAD}

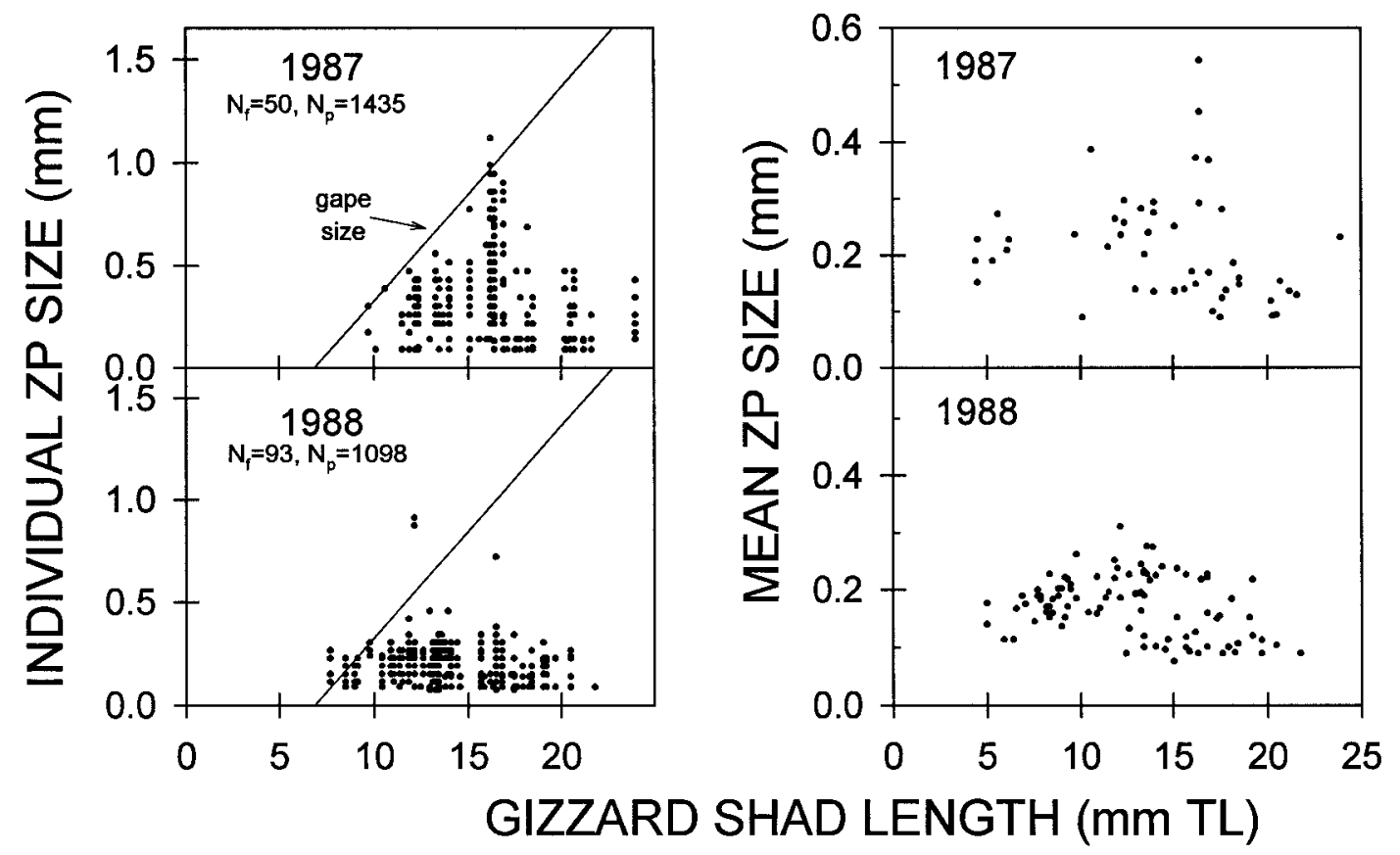

FigURE 5.- Relationship between individual prey ( $\mathrm{ZP}=$ zooplankton) size and fish total length (left panels) and between mean prey (ZP) size (averaged within individual fish) and fish total length (right panels) for gizzard shad in Kokosing Lake, Ohio during 1987 and 1988. Symbols are as in Figure 3.

lapped temporally in the limnetic zone. Larval white crappies occurred for 4-6 weeks, whereas larval gizzard shad occurred for 6-7 weeks, leading to almost complete temporal overlap during both years. Typically, larval gizzard shad appeared first, about 1 week before larval white crappies.

Patterns of white crappie foraging in Ohio reservoirs were described above. For larval gizzard shad, the range of prey sizes did not increase with fish size and may have declined slightly at lengths greater than $15 \mathrm{~mm}$ (Figure 5). Gape limitation appeared important until fish were $12 \mathrm{~mm}$ (1988) to $17 \mathrm{~mm}$ (1987), compared with $10 \mathrm{~mm}$ for larval white crappies. Mean prey size did not increase with gizzard shad size in either year, and actually declined with fish size in 1988 (1987: $F=2.5$, df $=1,67, P=0.12, r^{2}=0.03 ; 1988: F=6.4, \mathrm{df}$ $=1,91, P=0.01, r^{2}=0.06$; Figure 5), generally remaining below $0.30 \mathrm{~mm}$ (1988) to $0.40 \mathrm{~mm}$ (1987).

In contrast to patterns of crappie size selectivity described above, all sizes of gizzard shad exhibited positive or neutral selection for small $(<0.25 \mathrm{~mm})$ prey, and gizzard shad between 4 and $18 \mathrm{~mm}$ displayed neutral selection for $0.25-0.49-\mathrm{mm}$ prey (Figure 4). All sizes of gizzard shad showed negative selection for zooplankton $0.50 \mathrm{~mm}$ and larger (Figure 4). These results provide field confirmatory evidence for the laboratory experiments of Bremigan and Stein (1994), in which gizzard shad consistently and strongly exhibited positive selection for the smallest zooplankton $(0.2-0.4 \mathrm{~mm})$. The only prey taxa for which gizzard shad exhibited positive selection were rotifers and copepod nauplii.

\section{Discussion}

North-Temperate Natural Lakes (Large Zooplankton) versus Reservoirs (Small Zooplankton)

Zooplankton size composition differs between north-temperate natural lakes, where large zooplankton typically dominate zooplankton assemblages, and reservoirs, where small zooplankton predominate. For example, mean zooplankton size 
ranged from 0.4 to $1.3 \mathrm{~mm}$ in New York lakes (Mills et al. 1987), whereas mean zooplankton size in Ohio reservoirs is consistently less than 0.60 $\mathrm{mm}$ and often less than $0.40 \mathrm{~mm}$ (Bremigan, unpublished data; see also Canfield and Jones 1996 for discussion of zooplankton size in reservoirs in Iowa, Kansas, Missouri, and Oklahoma). Relative to our study, Lake Mendota differed most markedly from Ohio reservoirs in its high relative abundance of zooplankton greater than $1.0 \mathrm{~mm}$; in contrast, smaller zooplankton (particularly those $<0.50 \mathrm{~mm}$ ) dominated Ohio reservoirs. Thus, we fully expected that relationships between larval fish size (gape size) and prey size would differ between systems with different zooplankton size structure. However, in systems with both types of zooplankton assemblages, larval crappies greater than $8-10 \mathrm{~mm}$ were unlimited by gape size; maximum prey size consumed was typically less than $0.75 \mathrm{~mm}$. With a higher proportion of large zooplankton in north-temperate lakes, gape size should limit the size of prey consumed by larval crappies more strongly in north-temperate natural lakes than in reservoirs. In other words, we expected that mean prey size would be more strongly related to fish size over a broader larval size range in north-temperate natural lakes than in reservoirs. Though both relationships were positive, those from our Ohio reservoirs were actually stronger (i.e., correlation coefficients were larger) than those from Lake Mendota. Mean prey size of larval white crappies increased with fish length in Ohio reservoirs; however, when much larger zooplankton were available in Lake Mendota, surprisingly, mean prey size did not increase progressively with fish length. As such, prey selection patterns as a function of prey size did not differ between northtemperate natural lakes and reservoirs, in spite of the dramatic differences in zooplankton size structure. The generality of this result for white and black crappies across a wide geographical area and in systems that differ in a variety of ways (e.g., zooplankton size structure, impounded versus natural systems, etc., Thornton 1990; Wetzel 1990) suggests that larval crappies may be "hardwired" with regard to prey selection, consuming somewhat larger prey with increasing gape size, but continuing to select prey below their gape limitation.

\section{Gizzard Shad and White Crappie Comparisons}

Larval white crappies and gizzard shad possessed different gape size-fish length relationships, which translated into differences in prey size selection in the field. For any size, white crappies had a larger gape and thus were capable of consuming a wider range of prey sizes than gizzard shad. As such, prey size consumed by larval gizzard shad appeared restricted by their gape, through to larger sizes of larvae than larval white crappies.

Given the smaller gape size at length for gizzard shad relative to white crappies, we expected that mean prey size and fish length (as a surrogate for gape size) would be more strongly related for gizzard shad than for white crappies because of the prolonged gape limitation in gizzard shad. That is, maximum prey size would be more restricted by gape size for gizzard shad (i.e., up to $12-17 \mathrm{~mm}$ ) than for white crappies (i.e., up to $\sim 10 \mathrm{~mm}$ ). Because prey size selection by white crappies was restricted by gape size only through $10 \mathrm{~mm}$, mean prey size should not increase with fish size beyond $10 \mathrm{~mm}$. That is, once no longer constrained by gape size (i.e., at small sizes relative to gizzard shad), larval white crappie prey size should remain relatively constant. Contrary to our predictions, mean prey size consumed by gizzard shad was unrelated to fish size, whereas prey size and fish size were strongly related for white crappies (even when faced with a fairly narrow size range of available zooplankton). Thus, gizzard shad continued to consume small prey even when their gape increased, whereas larval white crappies prey size continually increased with gape size. Further, based on electivities, larval gizzard shad exhibited positive selection for small prey items regardless of gape limitation, whereas larval white crappies positively selected larger prey as they grew.

These differences probably reflect a combination of factors, including both gape effects (as considered here) and differences in foraging modes. Although both gizzard shad and white crappies are particulate-feeding zooplanktivores as larvae, their foraging modes change as they grow; white crappies continue to feed particulately, but gizzard shad switch to pump filter feeding (Overmann et al. 1980; Drenner et al. 1982a, 1982b; Hanson and Qadri 1984; O'Brien et al. 1984). At this point, white crappies will continue to select large prey, whereas gizzard shad should select those prey least able to escape predation (Drenner and McComas 1980). Though these differences clearly influence prey selection, particularly as fish grow, our results reveal that differences in gape are important, especially for larvae.

For larval crappies, these results agree with previous work, in which prey size was seen to increase 
with fish size (Overmann et al. 1980; Schael et al. 1991). However, for gizzard shad, results have been somewhat mixed. In the laboratory, as with our field results, larval gizzard shad that were no longer gape limited consistently consumed small prey regardless of availability (Bremigan and Stein 1994; this study). Conversely, Michaletz et al. (1987) suggested that zooplankton size increased with gizzard shad size, though this relationship was based on mean zooplankton prey size and mean gizzard shad sizes (i.e., not on data from individual zooplankton or fish) from six sample dates (i.e., fish were not separated by size, but variable-sized fish were combined within sample dates). Because fish sizes on any one sampling date can vary tremendously, relationships of prey size to fish size based on means and determined only on individual sample dates are difficult to interpret. In addition, the sizes of gizzard shad examined by Michaletz et al. (1987) appeared larger than the maximum size of fish examined herein, such that relationships generated by the two studies may reflect different gizzard shad life stages. As such, the field data reported in this paper are consistent with previous laboratory predictions (Bremigan and Stein 1994), in which size of zooplankton consumed did not increase with size of gizzard shad larvae.

Our analyses support the hypothesis that species-specific relationships among larval gape size, zooplankton size, and larval prey selection can influence patterns of recruitment and, ultimately, fish species distribution (Bremigan and Stein 1994). For larval gizzard shad, which consistently selected small zooplankton $(<0.25 \mathrm{~mm})$, recruitment should be favored in reservoirs that support high densities of zooplankton less than $0.25 \mathrm{~mm}$ but should be constrained in north-temperate lakes, in which zooplankton less than $0.25 \mathrm{~mm}$ are relatively rarer. Indeed, in north-temperate systems, gizzard shad recruitment is probably reduced by both large zooplankton size and overwinter mortality, relative to that in reservoirs. Because larval crappies preferred prey of a size $(0.25-1.0 \mathrm{~mm})$ that both did not differ between Lake Mendota and Ohio reservoirs and was available in similar proportion in both systems, successful recruitment of larval crappies should be possible in both northtemperate natural lakes and reservoirs.

Finally, will competition with larval gizzard shad negatively affect crappie recruitment in reservoirs? Our data reveal that larval crappies and gizzard shad diets overlap during co-occurrence in the limnetic zone of Ohio reservoirs. However, the range of fish sizes at which these species both positively selected similar prey sizes was small, with the resultant duration of overlap short. Even so, because gizzard shad consistently selected small zooplankton, were 500-4,000 times more abundant than were larval crappies (in Kokosing Lake; Bremigan et al. 1991), and performed better with small than large zooplankton (Bremigan and Stein 1997), we expect gizzard shad to outcompete larger-gaped crappies in reservoirs dominated by small zooplankton, particularly if zooplankton densities are low. Thus, both direct effects of zooplankton on larval fish (as influenced by zooplankton size and density) and competitive interactions among larval fishes (as influenced by spatial and temporal overlap) probably contribute to patterns of relative success of fish species across systems.

\section{Acknowledgments}

We thank E. Lewis, L. Ryan, H. Irvin, and C. Mallison for their help in the field and laboratory. Helpful comments were provided on a previous draft of this manuscript by E. Irwin, D. Partridge, S. Peyton, E. C. Webber, and three anonymous referees. This work was supported in part by DEB9108986 and DEB-9410323 to D.R.D., and by NSF BSR-8705518, DEB-9107173, DEB-9407859, and Federal Aid in Fish Restoration, project F-57-R to R.A.S., administered through the Ohio Division of Wildlife. This paper represents contribution 8965177 of the Alabama Agricultural Experiment Station.

\section{References}

Arts, M. T., and D. O. Evans. 1987. Precision micrometer for measurement of mouth gape of larval fish. Canadian Journal of Fisheries and Aquatic Sciences 44:1782-1785.

Bremigan, M. T., E. M. Lewis, M. B. Jones, R. A. Stein, and D. R. DeVries. 1991. Evaluating effects of stocking threadfin shad on young-of-year crappie, bluegill, and largemouth bass in Ohio lakes. Ohio Department of Natural Resources, Federal Aid in Sport Fish Restoration, Project F-57-R, Study 15, Final Report, Columbus.

Bremigan, M. T., and R. A. Stein. 1994. Gape-dependent larval foraging and zooplankton size: implications for fish recruitment across systems. Canadian Journal of Fisheries and Aquatic Sciences 51:913-922.

Bremigan, M. T., and R. A. Stein. 1997. Experimental assessment of the influence of zooplankton size and density on gizzard shad recruitment. Transactions of the American Fisheries Society 126:622-637.

Canfield, T. J., and J. R. Jones. 1996. Zooplankton abundance, biomass, and size-distribution in selected midwestern waterbodies and relation with trophic state. Journal of Freshwater Ecology 11:171-181. 
Chesson, J. 1978. Measuring preference in selective predation. Ecology 59:211-215.

Chesson, J. 1983. The estimation and analysis of preference and its relationship to foraging models. Ecology 64:1297-1304.

Crowder, L. B., M. E. McDonald, and J. A. Rice. 1987. Understanding recruitment mechanisms of Lake Michigan fishes: the importance of size-based interactions between fish and zooplankton. Canadian Journal of Fisheries and Aquatic Sciences 44(Supplement 2):141-147.

DeVries, D. R., and R. A. Stein. 1991. Comparing three zooplankton samplers: a taxon-specific assessment. Journal of Plankton Research 13:53-59.

DeVries, D. R., and R. A. Stein. 1992. Complex interactions between fish and zooplankton: quantifying the role of an open-water planktivore. Canadian Journal of Fisheries and Aquatic Sciences 49:12161227.

DeVries, D. R., R. A. Stein, J. G. Miner, and G. G. Mittelbach. 1991. Stocking threadfin shad: consequences for young-of-year fishes. Transactions of the American Fisheries Society 120:368-381.

Drenner, R. W., F. deNoyelles, Jr., and D. Kettle. 1982a. Selective impact of filter-feeding gizzard shad on zooplankton community structure. Limnology and Oceanography 27:965-968.

Drenner, R. W., and S. R. McComas. 1980. The roles of zooplankter escape ability and fish size selectivity in the selective feeding and impact of planktivorous fish. Pages 587-593 in W. C. Kerfoot, editor. Evolution and ecology of zooplankton communities. University Press of New England, Hanover, New Hampshire.

Drenner, R. W., W. J. O'Brien, and J. R. Mummert. 1982b. Filter-feeding rates of gizzard shad. Transactions of the American Fisheries Society 111:210215.

Guest, W. C., R. W. Drenner, S. T. Threlkeld, F. D. Martin, and J. D. Smith. 1990. Effects of gizzard shad and threadfin shad on zooplankton and young-ofyear crappie production. Transactions of the American Fisheries Society 119:529-536.

Haney, J. F., and D. J. Hall. 1973. Sugar-coated Daphnia: a preservation technique for Cladocera. Limnology and Oceanography 18:331-333.

Hansen, M. J., and D. H. Wahl. 1981. Selection of small Daphnia pulex by yellow perch fry in Oneida Lake, New York. Transactions of the American Fisheries Society 110:64-71.

Hanson, J. M., and S. U. Qadri. 1984. Feeding ecology of age-0 pumpkinseed (Lepomis gibbosus) and black crappie (Pomoxis nigromaculatus) in the Ottawa River. Canadian Journal of Zoology 62:613-621.

Houde, E. D. 1994. Differences between marine and freshwater fish larvae: implications for recruitment. ICES Journal of Marine Science 51:91-97.

Michaletz, P. H., D. G. Unkenholz, and C. C. Stone. 1987. Prey size selectivity and food partitioning among zooplanktivorous age-0 fishes in Lake Francis Case, South Dakota. American Midland Naturalist 117:126-138.
Miller, R. L., and T. J. Hall. 1987. Factors affecting black crappie young-of-the-year recruitment at Knox Lake, Ohio. Ohio Department of Natural Resources, Federal Aid in Sport Fish Restoration, Project F-29-R, Study 23, Final Report, Columbus.

Miller, T. J., L. B. Crowder, and F. P. Binkowski. 1990 Effects of changes in the zooplankton assemblage on growth of bloater and implications for recruitment success. Transactions of the American Fisheries Society 119:483-491.

Mills, E. L., D. M. Green, and A. Schiavone, Jr. 1987. Use of zooplankton size to assess the community structure of fish populations in freshwater lakes. North American Journal of Fisheries Management 7:369-378.

Mills, E. L., M. V. Pol, R. E. Sherman, and T. B. Culver. 1989a. Interrelationships between prey body size and growth of age-0 yellow perch. Transactions of the American Fisheries Society 118:1-10.

Mills, E. L., R. Sherman, and D. S. Robson. 1989b. Effects of zooplankton abundance and body size on growth of age-0 yellow perch (Perca flavescens) in Oneida Lake, NY, 1975-1986. Canadian Journal of Fisheries and Aquatic Sciences 46:880-886.

O'Brien, W. J., B. Loveless, and D. Wright. 1984. Feeding ecology of young white crappie in a Kansas reservoir. North American Journal of Fisheries Management 4:341-349.

Overmann, G. J., R. D. Hoyt, and G. A. Kindschi. 1980. The larval life history of the crappies (Pomoxis) spp. Transactions of the Kentucky Academy of Science 41(3-4):105-115.

Rice, J. A., L. B. Crowder, and M. E. Holey. 1987. Exploration of mechanisms regulating larval survival in Lake Michigan bloater: a recruitment analysis based on characteristics of individual larvae. Transactions of the American Fisheries Society 116: 703-718.

Rosenthal, H., and G. Hempel. 1970. Experimental studies in feeding and food requirements of herring larvae (Clupea harengus L.). Pages 344-364 in J. H. Steel, editor. Marine food chains. University of California Press, Berkeley.

Schael, D. M., L. G. Rudstam, and J. R. Post. 1991. Gape limitation and prey selection in larval yellow perch (Perca flavescens), freshwater drum (Aplodinotus grunniens), and black crappie (Pomoxis nigromaculatus). Canadian Journal of Fisheries and Aquatic Sciences 48:1919-1925.

Thornton, K. W. 1990. Perspectives on reservoir limnology. Pages 1-13 in K. W. Thornton, B. L. Kimmel, and F. E. Payne, editors. Reservoir limnology: ecological perspectives. Wiley, New York.

Toetz, D. W. 1966. The change from endogenous to exogenous sources of energy in bluegill sunfish larvae. Investigations of Indiana Lakes and Streams 7: 115-146.

Wetzel, R. G. 1990. Reservoir ecosystems: conclusions and speculations. Pages 227-238 in K. W. Thornton, B. L. Kimmel, and F. E. Payne, editors. Reservoir limnology: ecological perspectives. Wiley, New York. 
Wong, B., and F. J. Ward. 1972. Size selection of Daphnia pulicaria by yellow perch (Perca flavescens) fry in West Blue Lake, Manitoba. Journal of the Fisheries Research Board of Canada 29:1761-1764.

Zaret, T. M. 1980. Predation and freshwater commu- nities. Yale University Press, New Haven, Connecticut.

Received March 21, 1997

Accepted March 3, 1998 